\title{
Influence of Freezing and Freeze Drying on Intracellular Enzymatic Activity and Autolytic Properties of Some Lactic Acid Bacterial Strains
}

\author{
S. Kandil, M. El Soda* \\ Department of Dairy Science and Technology, Alexandria University, Alexandria, Egypt \\ Email: ${ }^{*}$ morsi elsoda@hotmail.com
}

Received 26 March 2015; accepted 29 May 2015; published 3 June 2015

Copyright (C) 2015 by authors and Scientific Research Publishing Inc.

This work is licensed under the Creative Commons Attribution International License (CC BY).

http://creativecommons.org/licenses/by/4.0/

(c) (i) Open Access

\begin{abstract}
Lactic acid bacteria possess several interesting properties of great economic importance. Improvement and stabilization of these industrially important features are an active research area at the present time. The objectives of this work are to study the effect of freezing and freeze-drying on the survival rate, autolytic activity and intracellular enzymatic activity of the main species of lactic acid bacteria used in the dairy industry. The article focused on several characteristics that were not well covered in the past. The obtained results revealed that both preservation methods have a significant effect on viability, autolytic activity and intracellular enzymatic activity. After six months of storage we found that frozen cultures exhibited higher survival rate, higher rate of intracellular enzymatic activity and lower rate of autolysis. The impact of conservation treatments was only strain specific in the case of survival rate. The results obtained lead to the selection of the best preservation method for the selected cultures based on survival rate, autolytic activity and intracellular enzymatic activity.
\end{abstract}

\section{Keywords}

Freeze-Drying, Freezing, Intracellular Enzymes, Lactic Acid Bacteria, Viability, Autolysis

\section{Introduction}

Lactic acid bacteria (LAB) are indispensable for the manufacture of a wide range of dairy products such as

${ }^{*}$ Corresponding author.

How to cite this paper: Kandil, S. and El Soda, M. (2015) Influence of Freezing and Freeze Drying on Intracellular Enzymatic Activity and Autolytic Properties of Some Lactic Acid Bacterial Strains. Advances in Microbiology, 5, 371-382.

http://dx.doi.org/10.4236/aim.2015.56039 
cheeses and fermented milks. They show a large number of metabolic activities responsible for flavor development and texture modification in these products; they can also play a role in the acceleration of cheese ripening and/or bitterness reduction [1]-[4].

The industrial use of LAB as starter cultures depends on the technological properties, concentration and preservation technologies, required to maintain high level of viability, acidification activity and enzymatic activity during long-term storage [5]-[8].

Freezing and freeze-drying are commonly used for the preservation and storage of starter cultures used in the dairy industry. These techniques can bring about undesirable side effects, such as membrane injury, protein and enzymes denaturation and DNA damage [9]-[12]. Several factors are relevant for the preparation of bacterial cultures that will have high number of cells and long term viability during storage. These include intrinsic factors, such as cell shape and size, genetic composition, and differences in cell wall and membrane composition, growth conditions, drying medium and storage conditions [13].

Their protective effect during drying and freezing was shown to be strain specific [14] [15]. Cells are usually harvested during the stationary phase of growth because they are reported to be less sensitive to environmental stresses compared to those harvested at the lag and exponential phases [16]-[19].

Drying medium contains cryoprotectants such as dextran; trehalose, sucrose, lactose, glucose, sorbitol, glycerol, proteins and skimmed milk have been demonstrated effective in improving survival of bacteria during freeze-drying and subsequent storage [20]-[23] by inhibiting the intracellular formation of ice, membranes damage, protein denaturation, etc., and decreasing therefore the cells injury. Several studies [13] [24]-[26] demonstrated that reconstituted skimmed milk powder should be selected as a drying medium for LAB.

Previous studies [27]-[29] revealed that cultivability is not enough to completely define viability. It might, therefore, be interesting to assess the changes in the physiological state during storage of frozen and freeze-dried strains by simultaneously measuring other technological parameters such as membrane integrity, esterase activity or proteolytic activity [30] and the autolytic properties which reflect the ability of the strains to liberate their intracellular enzymes [31], showed no correlation with survival rate after freezing or freeze-drying. The faster release of the intracellular proteolytic and lipolytic enzymes will contribute in flavor development during cheese ripening and may lead to acceleration of the ripening process [32] [33].

Work on the impact of the conservation methods on intracellular enzymatic activities and autolytic properties is very limited; therefore, the aim of the present investigation is to study the impact of freezing and freeze-drying on the survival rate, autolytic activity and intracellular enzymatic activities of different lactic acid bacterial species using skimmed milk with glycerol as a cryoprotective media.

\section{Materials and Methods}

\subsection{Bacterial Strains and Culture Conditions}

A total of 26 lactic acid bacterial (LAB) strains tested in this study were obtained from the culture collection of the Laboratory of Biochemistry of Dairy Microorganisms (LBDM), Faculty of Agriculture, Alexandria University. All strains originated from traditional Egyptian dairy products; cheeses (Domiatti and Ras) and fermented milk (Zabady and Laban Rayeb). These strains belong to several genera of LAB; Lactobacillus, Streptococcus, Lactococcus, Enterococcus. The FAAU numbers and species of tested bacterial strains are given in Table 1 . The Lactobacillus strains were grown on MRS medium (Biolife, Milano, Italy) [34], while Streptococcus, Lactococcus and Enterococcus strains were grown on M17 medium (Biolife, Milano, Italy) [35]. The strains were grown at the optimum growth temperature; $30^{\circ} \mathrm{C}$ for Lactococcus, $37^{\circ} \mathrm{C}$ for mesophilic lactobacilli and $42^{\circ} \mathrm{C}$ for thermophilic lactobacilli and streptococci.

\subsection{Cryoprotective Medium}

The selected strains were frozen and freeze-dried in skimmed milk 10\% (w/v) with 2\% glycerol.

\subsection{Preparation of Cultures for Freezing and Freeze-Drying}

The microorganisms were sub-cultured four times in the specific medium for each genus. This medium was inoculated with $10 \%$ of the active culture. The growth phase was monitored by measuring the absorbance at 650 nm using Laxco spectrophotometer (model a1202, USA). At the early stationary phase, the medium was divided 
Table 1. List of the species and FAAU no. of the tested strains.

\begin{tabular}{cccc}
\hline No. & Species & \multicolumn{2}{c}{ FAAU No. } \\
\hline 1 & Lactobacillus delbrueckii subsp. bulgaricus & FAAU 1 & FAAU 2 \\
2 & Lactobacillus delbrueckii subsp. lactis & FAAU 7 & FAAU 4 \\
3 & Lactobacillus helveticus & FAAU 11 & FAAU 12 \\
4 & Lactobacillus acidophilus & FAAU 25 & FAAU 87 \\
5 & Lactobacillus paracasei subsp. paracasei & FAAU 10 & FAAU 9 \\
6 & Lactobacillus plantarum & FAAU 34 & FAAU 36 \\
7 & Lactobacillus rhamnosus & FAAU 64 & FAAU 65 \\
8 & Lactobacillus fermentum & FAAU 58 & FAAU 59 \\
9 & Lactobacillus brevis & FAAU 60 & FAAU 61 \\
10 & Streptococcus thermophillus & FAAU 16 & FAAU 17 \\
11 & Lactococcus lactis subsp. lactis & FAAU 19 & FAAU 43 \\
12 & Lactococcus lactis subsp. cremoris & FAAU 47 & FAAU 52 \\
\hline
\end{tabular}

into 2 parts $(100 \mathrm{ml}$ and $1000 \mathrm{ml})$. The cells were then harvested by centrifugation at $4000 \mathrm{rpm}$ for 20 minutes at $4^{\circ} \mathrm{C}$. The resulting pellet was then washed twice with $0.01 \mathrm{M}$ potassium phosphate buffer $\mathrm{pH}$ 7.0. The pellet resulting from the $100 \mathrm{ml}$ was used for the determination of the intracellular enzymatic activity and autolytic activity at zero time. While pellet resulting from $1000 \mathrm{ml}$ was dissolved in $100 \mathrm{ml}$ of the cryoprotective medium for the subsequent freezing and freeze-drying treatment.

\subsection{Freeze-Drying Conditions}

Each bacterial suspension was dispensed into $2 \mathrm{ml}$ vials. Samples were frozen at $-80^{\circ} \mathrm{C}$ for 24 hrs then subjected to freeze-drying. The freeze-drying process was performed in the Zirbus freeze-dryer (Vaco-5-ll-D, Germany), which was programmed to operate as follows; first primary drying for 20 hrs and 0.6 mbar chamber pressure followed by secondary drying for 2 hrs at $15^{\circ} \mathrm{C}$ shelf temperature and 0.4 mbar chamber pressure.

\subsection{Storage Conditions}

After the end of the freeze-drying cycle, the vials were sealed under vacuum and stored at $-20^{\circ} \mathrm{C}$. Frozen samples were stored at $-80^{\circ} \mathrm{C}$.

\subsection{Determination of Survival Rate}

Bacterial counts were determined after 48 hrs of incubation at optimum growth temperature using decimal dilutions of the samples with sterile peptone water. After freeze drying, pellets were rehydrated for 10 min at room temperature to the original volume using peptone water then cell count was determined [36]. Bacterial survival rate (\%) was calculated according to the formula

$$
\text { Survival rate }(\%)=\left(N / N_{o}\right) \times 100
$$

$N_{o}$ represents the log of colony forming units before freeze-drying.

$N$ represents the log of colony forming units after freeze-drying or freezing.

The survival rates during storage were evaluated at zero time, first day of freeze-drying and after 1, 3 and 6 months.

\subsection{Determination of Cell Autolytic Activity}

Cells were harvested by centrifugation and washed twice with $0.01 \mathrm{M}$ potassium phosphate buffer $\mathrm{pH}$ 7.0. The 
resulting pellet was then re-suspended in potassium phosphate buffer (10 mmol/l, pH 5.5) containing $1 \mathrm{~mol} / \mathrm{l}$ $\mathrm{NaCl}$ and diluted to $\mathrm{OD}_{650}$ equal 1.0 using Laxco spectrophotometer (model a1202, USA). The rate of autolysis was determined according the method described by Thiboutot et al. (1995) [37]. The autolytic properties were determined as the percentage decrease in the absorbance at $650 \mathrm{~nm}$ at different time intervals.

\subsection{Determination of Intracellular Enzymatic Activity}

\subsubsection{Preparation of the Crude Cell Free Extract}

Cells were harvested by centrifugation and washed twice with $0.01 \mathrm{M}$ potassium phosphate buffer $\mathrm{pH}$ 7.0. The resultant pellet was grinded for 20 minutes in mortar using alumina (Sigma Type A-5), the extracted disrupted cells re-suspended in $0.01 \mathrm{M}$ potassium phosphate buffer equivalent to $1 / 3$ of the original volume. The suspension was then centrifuged at $4000 \mathrm{rpm}$ for 20 minutes at $4^{\circ} \mathrm{C}$ using a high speed centrifuge (Sigma 6k15-Germany) as described by El-Soda and Desmazeaud (1982) [38].

\subsubsection{Aminopeptidase Activity}

Aminopeptidase activity in the crude cell free extract was measured using Leucine para-nitroanilide (Sigma, St. Louis, Missouri, USA) as a substrate according to the method of El-Soda and Desmazeaud (1982) [38] A unit of aminopeptidase activity was defined as the variation of 0.01 unit of absorbance at $420 \mathrm{~nm}$ in $1 \mathrm{~min}$ for $1 \mathrm{ml}$ enzyme of the different strains under previously described assay conditions. The specific activity was defined as the number of activity units/mg of protein.

\subsubsection{Esterase Activity}

The esterase activity was measured using Para-nitro phenyl butyrate as a substrate as described by Brandle and Zizer (1973) [39]. A unit of esterase activity was defined as the variation of 0.01 unit of absorbance at $420 \mathrm{~nm}$ in $1 \mathrm{~min}$ for $1 \mathrm{ml}$ enzyme of the different strains under previously described assay conditions. The specific activity was defined as the number of activity units/mg of protein.

\subsubsection{Protein Determination}

The protein concentration was estimated according to the method of Lowry et al., (1951) [40], using the Folin \& Ciocalteu's phenol reagent with bovine serum albumin as standard.

\subsection{Statistical Analysis}

F-test and analysis of variance of treatments difference was performed in randomized complete design according to Steel and Torrie (1980) [41]. Statistical analysis was done by ANOVA, F-test and L.S.D procedures available within the SAS software package (9.13.2009).

\section{Results}

\subsection{Effect of Freezing and Freeze-Drying on the Survival Rate}

Table 2 shows the results of the survival rates of the tested strains at the first day of freeze-drying and during the storage period (1, 3, and 6 months) for both frozen and freeze-dried cultures. There was a significant decrease of the survival rates of frozen and freeze-dried samples. The survival rates at the first day of freeze-drying ranged from 92 to 99.5\%, after 6 months of storage, the obtained results revealed that the survival rate was strain related, Streptococcus thermophillus, Lactococcus lactis subsp. lactis, Lactococcus lactis subsp. cremoris and Enterococcus faecium had the highest survival rate which ranged from 95\% - 98.6\%, while Lactobacillus helveticus and Lactobacillus plantarum showed the lowest survival rate $(72.7 \%-76.9 \%)$. Whereas the survival rates for frozen cultures after one month of storage ranged from 86.2\% - 99.4\%. After 6 months of storage values decreased gradually to reach $96.5 \%$ for Streptococcus thermophillus and Lactobacillus delbrueckii subsp. Lactis and $81 \%$ for Lactobacillus delbrueckii subsp. bulgaricus and Lactobacillus brevis.

\subsection{Effect of Freezing and Freeze-Drying on the Autolytic Activity}

The autolytic properties were evaluated in order to quantify the ability of the strains to liberate their intracellular enzymes which can then play an important role during the ripening process [31]. 
Table 2. Effect of freezing and freeze-drying on survival rate\%.

\begin{tabular}{|c|c|c|c|c|c|c|c|c|c|}
\hline \multirow{2}{*}{\multicolumn{2}{|c|}{$\begin{array}{c}\text { Treatment } \\
\text { Time }\end{array}$}} & \multicolumn{3}{|c|}{ After Freezing (Month) } & \multicolumn{4}{|c|}{ After Freeze-Drying (Month) } & \multirow{2}{*}{ Mean } \\
\hline & & 1 & 3 & 6 & Zero Time Treatment & 1 & 3 & 6 & \\
\hline \multirow{27}{*}{ 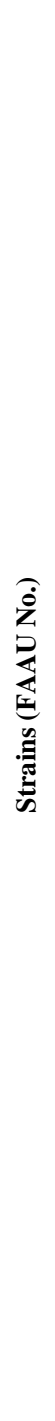 } & 1 & 97.80 & 96.80 & 96.40 & 99.35 & 96.10 & 95.50 & 94.20 & $97.615^{\mathrm{g}}$ \\
\hline & 2 & 99.30 & 97.90 & 95.40 & 97.10 & 94.50 & 94.40 & 87.60 & $96.62^{\mathrm{j}}$ \\
\hline & 7 & 98.90 & 97.10 & 95.30 & 95.60 & 94.80 & 94.20 & 93.30 & $96.92^{\mathrm{ij}}$ \\
\hline & 4 & 98.80 & 95.10 & 92.40 & 98.50 & 97.40 & 95.60 & 94.50 & $97.23^{\text {hi }}$ \\
\hline & 11 & 97.90 & 94.10 & 91.70 & 99.10 & 94.10 & 84.00 & 73.50 & $93.44^{1}$ \\
\hline & 12 & 95.20 & 90.70 & 87.50 & 93.10 & 87.10 & 81.70 & 72.20 & $90.75^{\mathrm{m}}$ \\
\hline & 25 & 91.75 & 90.00 & 84.50 & 93.60 & 93.00 & 92.35 & 88.80 & $93.4^{1}$ \\
\hline & 87 & 92.00 & 89.25 & 84.00 & 94.20 & 93.10 & 92.50 & 89.45 & $93.45^{1}$ \\
\hline & 10 & 97.10 & 94.50 & 92.30 & 96.90 & 96.50 & 96.20 & 96.00 & $96.95^{\mathrm{ij}}$ \\
\hline & 9 & 99.80 & 99.20 & 96.30 & 99.70 & 99.50 & 95.60 & 95.50 & $98.56^{\text {cde }}$ \\
\hline & 34 & 99.20 & 98.00 & 90.00 & 98.50 & 98.40 & 98.00 & 98.00 & $98.0^{1 \mathrm{f}}$ \\
\hline & 36 & 99.40 & 98.20 & 96.30 & 98.90 & 98.80 & 98.60 & 98.20 & $98.84^{\mathrm{abc}}$ \\
\hline & 64 & 90.00 & 86.00 & 83.30 & 99.30 & 98.10 & 92.50 & 83.30 & $93.25^{1}$ \\
\hline & 65 & 91.00 & 86.50 & 83.00 & 87.80 & 86.40 & 83.30 & 78.50 & $89.65^{\mathrm{n}}$ \\
\hline & 58 & 98.50 & 98.00 & 97.90 & 99.50 & 99.20 & 98.80 & 98.10 & $99^{\mathrm{ab}}$ \\
\hline & 59 & 98.50 & 97.30 & 93.50 & 99.00 & 99.00 & 98.80 & 96.70 & $98.28^{\text {ef }}$ \\
\hline & 60 & 98.90 & 98.60 & 90.60 & 98.70 & 98.60 & 97.90 & 97.20 & $98.05^{\mathrm{f}}$ \\
\hline & 61 & 98.20 & 97.40 & 97.00 & 98.50 & 98.10 & 97.80 & 97.30 & $98.43^{\mathrm{de}}$ \\
\hline & 16 & 98.50 & 96.70 & 93.70 & 97.20 & 97.00 & 95.50 & 94.90 & $97.35^{\text {gh }}$ \\
\hline & 17 & 99.50 & 98.20 & 97.90 & 99.55 & 97.80 & 97.50 & 96.60 & $98.705^{\mathrm{bcc}}$ \\
\hline & 19 & 99.50 & 97.80 & 95.20 & 99.50 & 99.80 & 99.40 & 98.60 & $98.98^{\mathrm{ab}}$ \\
\hline & 43 & 99.90 & 98.80 & 98.50 & 99.25 & 99.00 & 98.60 & 96.70 & $99.075^{\mathrm{a}}$ \\
\hline & 47 & 97.50 & 97.20 & 97.10 & 98.40 & 96.80 & 90.00 & 84.20 & $96.12^{\mathrm{k}}$ \\
\hline & 52 & 100.00 & 99.00 & 99.00 & 99.50 & 97.20 & 92.00 & 83.50 & $97.02 \mathrm{i}$ \\
\hline & 48 & 99.20 & 98.00 & 96.30 & 100.00 & 99.60 & 99.00 & 98.50 & $99.06^{\mathrm{a}}$ \\
\hline & \multirow[t]{2}{*}{49} & 99.00 & 98.80 & 98.50 & 99.00 & 98.50 & 95.00 & 91.60 & $98.04^{\mathrm{f}}$ \\
\hline & & \multicolumn{3}{|c|}{$97.3^{\mathrm{a}}$} & \multicolumn{4}{|c|}{$96^{\mathrm{b}}$} & \\
\hline
\end{tabular}

${ }^{\mathrm{a}-\mathrm{n}}$ Means followed by the same letter's are not significant, but different letters are significant according to LSD procedure (P $\left.<0.05\right)$.

Table 3 revealed an increase in autolytic activity for frozen and freeze-dried cultures, the obtained results for freeze-dried cultures showed that the lowest autolytic activity after the first day of freeze-drying was $14 \%$ for Enterococcus faecium, while the highest autolytic activity was 62\% for Lactobacillus plantarum and Lactobacillus rhamnosus. When both treatments were compared the obtained data revealed that freeze-drying had a higher impact on autolytic activity (31.28\%) than freezing (27.81\%). As a general rule Lactobacillus strains exhibited higher rate of autolysis when compared to Streptococcus thermophillus, Lactococcus lactis subsp. lactis, Lactococcus lactis subsp. cremoris and Enterococcus faecium strains.

\subsection{Effect of Freezing and Freeze-Drying on the Intracellular Enzymatic Activity}

The aminopeptidase activity of the tested cultures at the first day of freeze-drying and after 3 and 6 months of the storage period is illustrated in Figure 1. The obtained data revealed that Lactobacillus paracasei subsp. paracasei had aminopeptidase specific activity of 3.18 which was the highest among all the species tested. The 


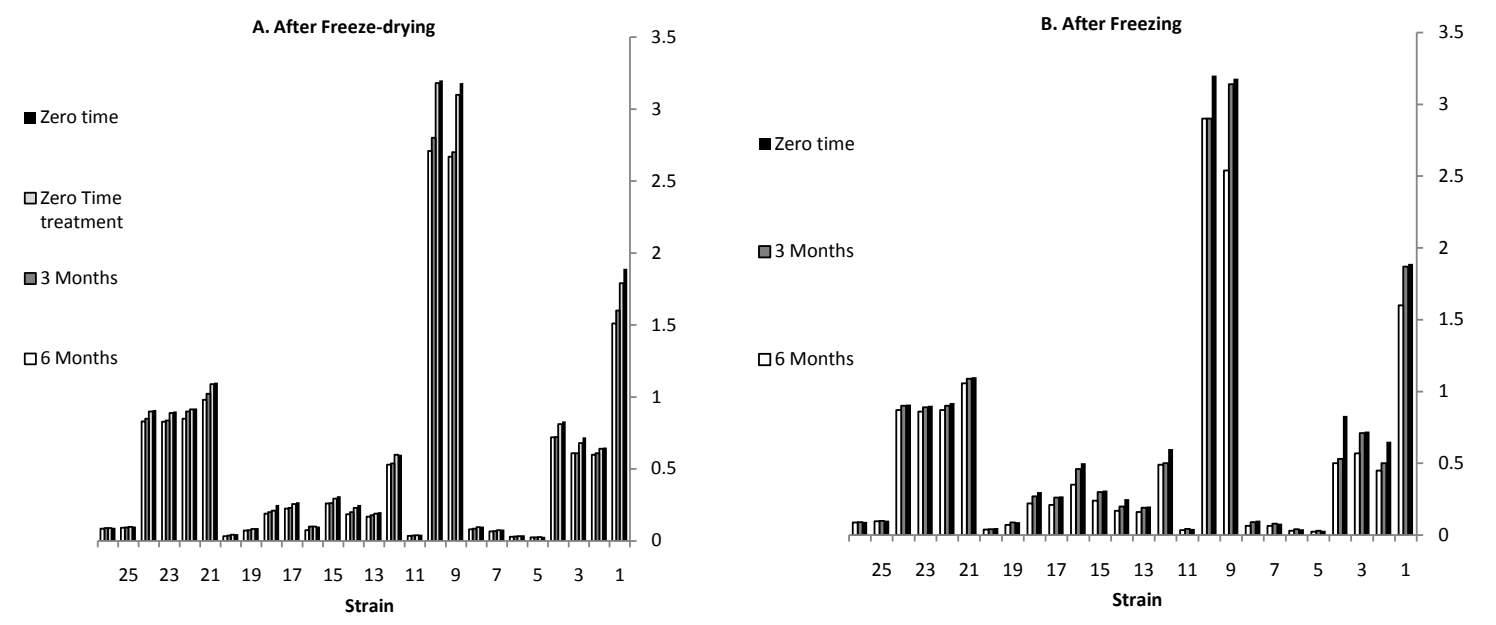

Figure 1. Aminopeptidase activities of tested strains at zero time and after freezing, freeze-drying and during storage period.

Table 3. Effect of freezing and freeze-drying on the autolytic activity.

\begin{tabular}{|c|c|c|c|c|c|c|c|c|c|c|}
\hline \multirow{2}{*}{\multicolumn{2}{|c|}{$\begin{array}{c}\text { Treatment } \\
\text { Time }\end{array}$}} & \multicolumn{4}{|c|}{ After Freezing (Month) } & \multicolumn{4}{|c|}{ After Freeze-Drying (Month) } & \multirow[b]{2}{*}{ Mean } \\
\hline & & Zero Time & 1 & 3 & 6 & $\begin{array}{l}\text { Zero Time } \\
\text { Treatment }\end{array}$ & 1 & 3 & 6 & \\
\hline \multirow{27}{*}{ 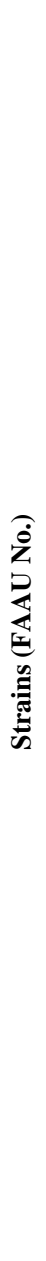 } & 1 & 47.00 & 69.00 & 70.00 & 72.00 & 62.00 & 67.00 & 68.00 & 70.00 & $61.9^{\mathrm{a}}$ \\
\hline & 2 & 33.00 & 51.00 & 60.00 & 65.00 & 40.00 & 50.00 & 52.00 & 53.00 & $47^{d}$ \\
\hline & 7 & 40.00 & 53.00 & 55.00 & 57.00 & 50.00 & 50.50 & 51.00 & 54.00 & $49.05^{c}$ \\
\hline & 4 & 35.00 & 41.00 & 47.00 & 55.00 & 41.10 & 42.50 & 47.00 & 50.80 & $42.94^{f}$ \\
\hline & 11 & 20.00 & 21.50 & 22.10 & 24.10 & 22.10 & 24.80 & 27.70 & 29.60 & $23.19^{\circ}$ \\
\hline & 12 & 40.00 & 51.00 & 56.00 & 58.00 & 45.00 & 72.00 & 73.00 & 75.00 & $55^{b}$ \\
\hline & 25 & 30.00 & 36.20 & 42.00 & 48.20 & 31.60 & 32.50 & 36.20 & 39.00 & $35.57^{\mathrm{i}}$ \\
\hline & 87 & 32.00 & 35.00 & 39.00 & 47.00 & 35.00 & 45.00 & 50.00 & 60.00 & $40.7^{g}$ \\
\hline & 10 & 22.00 & 31.00 & 32.50 & 34.90 & 22.00 & 21.00 & 22.50 & 25.30 & $26.32^{\mathrm{m}}$ \\
\hline & 9 & 29.00 & 31.00 & 33.50 & 35.50 & 38.60 & 39.00 & 40.70 & 41.40 & $34.67^{j}$ \\
\hline & 34 & 19.00 & 20.50 & 22.00 & 25.00 & 22.00 & 23.50 & 24.60 & 26.50 & $22.11^{b}$ \\
\hline & 36 & 15.00 & 15.50 & 16.00 & 17.20 & 16.70 & 17.50 & 24.00 & 27.40 & $17.93^{s}$ \\
\hline & 64 & 30.00 & 39.00 & 44.00 & 54.50 & 48.00 & 55.50 & 60.00 & 66.50 & $45.75^{\mathrm{e}}$ \\
\hline & 65 & 30.00 & 31.00 & 31.80 & 33.90 & 34.80 & 40.00 & 51.90 & 53.50 & $36.69^{\mathrm{h}}$ \\
\hline & 58 & 19.00 & 20.90 & 28.00 & 38.70 & 21.90 & 34.00 & 34.60 & 62.00 & $29.71^{1}$ \\
\hline & 59 & 14.00 & 14.90 & 28.90 & 31.70 & 19.00 & 19.90 & 26.00 & 27.00 & $20.94^{q}$ \\
\hline & 60 & 20.00 & 22.20 & 28.20 & 36.20 & 27.50 & 31.00 & 31.30 & 35.30 & $27.17^{\mathrm{m}}$ \\
\hline & 61 & 20.50 & 22.80 & 25.60 & 27.50 & 34.80 & 37.40 & 45.80 & 56.00 & $31.14^{k}$ \\
\hline & 16 & 19.00 & 19.70 & 30.80 & 42.60 & 20.20 & 22.60 & 23.00 & 27.60 & $24.35^{n}$ \\
\hline & 17 & 12.00 & 13.00 & 13.50 & 19.40 & 12.90 & 22.00 & 26.00 & 28.90 & $17.17^{\mathrm{s}}$ \\
\hline & 19 & 12.00 & 13.00 & 14.70 & 23.40 & 23.60 & 24.80 & 29.00 & 35.90 & $20.04^{\mathrm{r}}$ \\
\hline & 43 & 11.00 & 12.30 & 18.50 & 20.50 & 11.20 & 12.20 & 13.20 & 13.60 & $13.45^{\mathrm{u}}$ \\
\hline & 47 & 5.00 & 8.00 & 10.00 & 15.90 & 5.10 & 9.30 & 11.10 & 16.90 & $9.13^{w}$ \\
\hline & 52 & 6.00 & 8.50 & 11.00 & 14.80 & 8.00 & 9.50 & 11.00 & 16.80 & $9.72^{w}$ \\
\hline & 48 & 9.50 & 12.00 & 17.20 & 27.50 & 13.90 & 14.00 & 17.20 & 20.20 & $15.05^{t}$ \\
\hline & 49 & 6.00 & 14.00 & 16.50 & 18.30 & 8.50 & 10.00 & 12.00 & 18.20 & $11.55^{\mathrm{v}}$ \\
\hline & & & & & & & 31.2 & & & \\
\hline
\end{tabular}

${ }^{\mathrm{a}-\mathrm{w}}$ Means followed by the same letter's are not significant, but different letters are significant according to LSD procedure (P $<0.05$ ). 
aminopeptidase activity of Lactobacillus strains was higher when compared to Streptococcus thermophillus, Lactococcus lactis subsp. lactis, Lactococcus lactis subsp. cremoris and Enterococcus faecium strains.

As a general rule conservation methods lead to a significant decrease of aminopeptidase activity, which was in favor of freeze-drying. In fact the decrease ranged from $10 \%-20 \%$ for freeze-dried cultures, while corresponding values in the case of freezing were $7 \%-16 \%$. Similar trends was observed for esterase activity (Figure 2)

Figure 2 which illustrate the esterase activity of the tested cultures at the first day of freeze-drying and after 3 and 6 months of storage period, show that Lactobacillus cultures exhibited lower esterase activity when compared to Streptococcus thermophillus, Lactococcus lactis subsp. lactis, Lactococcus lactis subsp. cremoris and Enterococcus faecium.

\section{Discussion}

Freeze-drying and freezing are commonly used for the preservation and storage of microorganisms for industrial application. The optimal performance of starter cultures should guarantee their potential to survive and the stabilization of their metabolic activity. In the present work we assessed the survival conditions of 26 LAB strains exhibiting technological potential during freeze-drying and freezing over a storage period of six months.

Our data revealed a significant reduction of survival during storage of the frozen and freeze-dried strains. Similar observations were reported for freeze-dried cultures such as Lactobacillus plantarum, Lactobacillus fermentum, Lactobacillus para mesenteroides, Lactobacillus mesenteroides ssp. mesenteroides [42], Lactococcus lactis ssp. lactis var. diacetylactis [43], Lactobacillus paracasei [24], Streptococcus thermophilus [44] and Lactobacillus acidophilus [45]. As well as frozen cultures such as Lactobacillus rhamnosus [46], Lb. delbrueckii subsp. bulgaricus [8] [29] [47], Streptococcus thermophilus [48]. Loss of the viability of freeze-dried cultures is a consequence of cell damage at several target sites, namely the cell wall, the cell membrane and the DNA, as well as a result of membrane lipid oxidation [49]. Also during freeze-drying, bacterial cells are subjected to osmotic stress as a result of decreased water activity of the medium and the external increase of accumulated solutes. While, freezing causes different cellular injuries on LAB [46], damage to cells due to formation of ice crystals and high osmotic pressure brought about by high internal solute concentrations [4] [6] [8]. However resistance to osmotic stress of strains is dependent on their ability to accumulate internal solutes which increases internal osmotic pressure and restores pressure and on changes in the membrane lipid composition [50]. Teixeria et al. (1996) [51] suggested that oxidation of the fatty acids of membrane lipids is the most likely cause of death of microbial cells during storage.

Our data revealed that Streptococcus thermophillus, Lactococcus lactis subsp. lactis and Lactococcus lactis subsp. cremoris had higher survival rate when compared to lactobacilli. Similar observations were reported by Heckly (1961) [52] who showed that the gram-positive cocci are the most resistant cultures. Also According toFonseca et al. (2000) [29], the higher the surface area of the cell, the higher the membrane damage owing to extracellular ice crystal formation during freezing. A similar relation also appears to exist for survival during

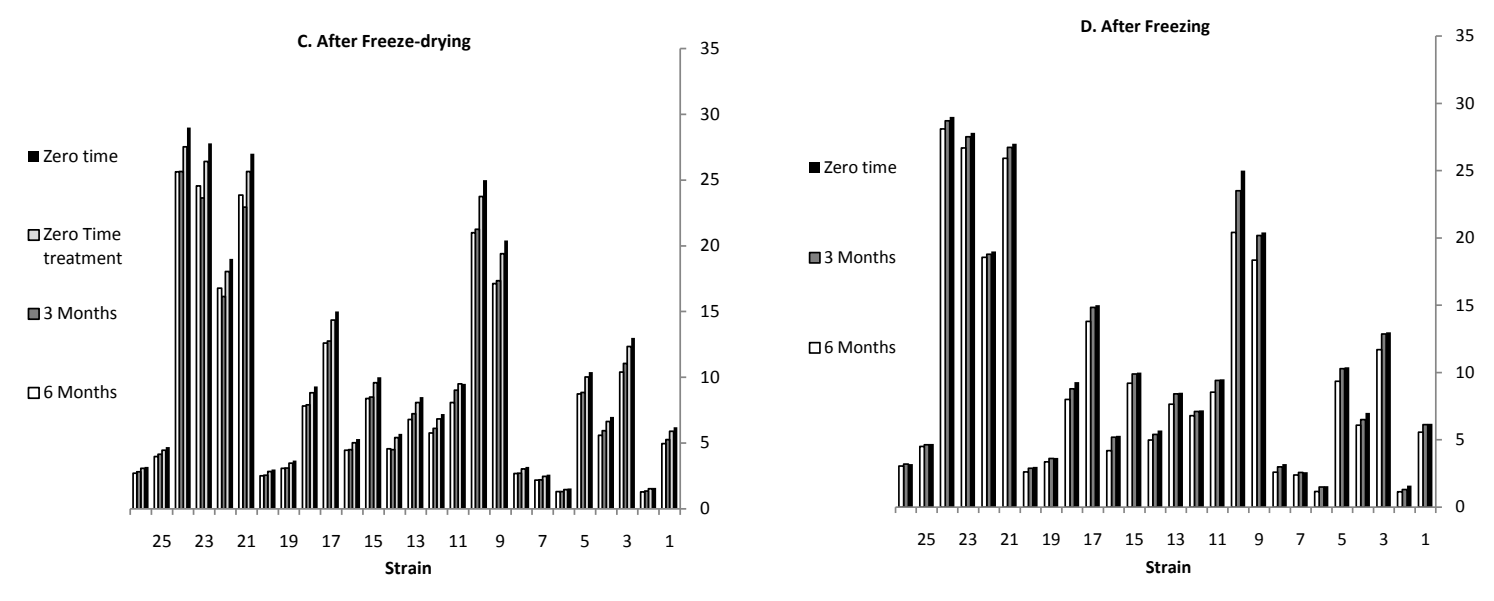

Figure 2. Esterase activities of tested strains at zero time and after freezing, freeze-drying and during storage period. 
storage of LAB in the freeze-dried state [6]. The different survival rates of tested Lactobacillus strains confirmed that resistance to freeze-drying is strain-specific [20] [36].

Consequence to previous data, specific sections as intrinsic factors, growth factors, sub-lethal treatments, drying medium and storage and rehydration should be controlled for the improvement of LAB survival during freeze-drying and subsequent storage [53]-[56], and several factors during storage affect survival and fermentation activity, including reaction with oxygen, moisture, light, microbial contamination and elevated temperature [19].

Our results showed no significant correlations between autolytic activity and survival rate to freezing or freeze-drying a similar observation were made by Koch et al., 2008 [57].

Intracellular enzymatic activity was significantly decreased by both treatments freezing and freeze-drying. The depression in the intracellular enzymatic activity may be due to several factors; theoretically a cell freezedried without injury, and stored under ideal conditions, should rehydrate to its original state, however, cells injured during freezing or freeze-drying, even if stored under perfect conditions, could gradually deteriorate, or could be killed by improper rehydration. Freeze-drying procedure might cause injury of cell envelopes resulting in the release of some intracellular materials [46] [58]. This may explain the correlation that we found between the increase of autolytic activity and the loss of enzymatic activity. These results are comparable data showing that the strains exhibiting higher in autolytic activity are more susceptible to decrease in intracellular enzymatic activity.

The obtained results revealed that Lactobacillus strains exhibited higher rate of autolysis than spherical shape strains these results are comparable to the data of other researchers who reported that the ability of strains to lyse and subsequent release of their intracellular enzymes is strain dependent [59]. Autolytic activity is an interesting property of lactic acid bacteria since it allows the liberation of intracellular enzymes into the cheese curd. These enzymes accelerate proteolysis during cheese ripening, which lead to an increase in the rate of free amino acid production that may act as flavor precursors [59] [60]. LAB that are highly autolytic are often used as primary or secondary starters for production of semi-hard and hard cheeses [61]-[63].

It is important to clarify that the presence of cryoprotectant help maintaining good viability and technological properties, which could referred to its ability to modify the dynamics of formation and rupture of intra- and intermolecular weak chemical bonds by mechanisms such as 1) alterations in the viscosity in the bacterial cell; 2) direct participation of the cryoprotectant in the intermolecular interactions; 3) modification of the water activity inside the bacteria; 4) alterations in the nucleation pattern by retarding the formation and/or changing the dimensions of the ice nuclei during solidification..

\section{Conclusions}

The impact of freezing and freeze-drying on the viability of 26 LAB strains representing 13 different species in presence of skimmed milk as a cryoprotectant was minimal.

Cocci were more resistant to both conservation methods than rod shape bacteria. Freezing was less damaging than freeze-drying. The method used for freezing cycles as well as freeze-drying cycles and cryoprotectant used in the study could be recommended for LAB preservation.

Thirty percent increase in the rate of autolysis could be measured as a consequence of culture conservation. The impact of freeze-drying on the rate of autolysis was slightly higher than freezing. Lactobacilli and more particularly Lactobacillus plantarum and Lactobacillus rhamnosus were found to be more sensitive than Streptococcus thermophillus, Lactococcus lactis subsp. lactis, Lactococcus lactis subsp. cremoris and Enterococcus faecium. Our data in that perspective indicate the possible use of conservation method to induce enzyme release from adjunct cultures during cheese ripening. The impact of freezing cycles and freeze-drying cycles should however be considered.

Intracellular aminopeptidase and esterase activity were affected by the conservation methods. An average reduction of about $14 \%$ could be measured. The difference between the impact of both methods is minimal. The decrease in the rate of both enzymatic activities was rather similar.

As a general rule the decrease in intracellular aminopeptidase and esterase activity of Streptococcus thermophillus, Lactococcus lactis subsp. lactis, Lactococcus lactis subsp. cremoris and Enterococcus faecium was less when compared to lactobacilli.

The impact of conservation method on the rate of autolysis and intracellular aminopeptidase and esterase ac- 
tivities which was not well investigated in the past can open new perspectives in flavor enhancement and accelerate cheese ripening research.

\section{Acknowledgements}

The author would like to gratefully acknowledge the Science and Technology Development Fund (STDF) for funding the project ID = 2036 entitled Establishment of a lactic acid bacterial culture collection for the food fermentation industry. Thanks are also due to Noha Atef Mohamed and Orchid Al-Badry Hassan for helping in parts of the experimental work.

\section{References}

[1] Habibi-Najafi, M.B. and Lee, B.H. (1996) Bitterness in Cheese: A Review. Critical Reviews in Food Science and Nutrition, 36, 397-411. http://dx.doi.org/10.1080/10408399609527733

[2] Giraffa, G. and Mora, D. (1999) DNA Probe for Lactobacillus delbrueckii subsp. lactis. Journal of Dairy Research, 66, 303-311. http://dx.doi.org/10.1017/S002202999900343X

[3] Leroy, F. and De Vuyst, L. (2004) Lactic Acid Bacteria as Functional Starter Cultures for the Food Fermentation Industry. Food Science and Technology, 15, 67-78. http://dx.doi.org/10.1016/j.tifs.2003.09.004

[4] Santivarangkna, C., Kulozik, U. and Foerst, P. (2007) Alternative Drying Processes for the Industrial Preservation of Lactic Acid Starter Cultures. Biotechnology Progress, 23, 302-315. http://dx.doi.org/10.1021/bp060268f

[5] Conrad, P.B., Miller, D.P., Cielenski, P.R. and de Pablo, J.J. (2000) Stabilization and Preservation of Lactobacillus acidophilus in Saccharide Matrices. Cryobiology, 41, 17-24. http://dx.doi.org/10.1006/cryo.2000.2260

[6] Carvalho, A.S., Silva, J., Ho, P., Teixeira, P., Malcata, F.X. and Gibbs, P. (2003) Effect of Various Growth Media upon Survival during Storage of Freeze-Dried Enterococcus faecalis and Enterococcus durans. Journal of Applied Microbiology, 94, 947-952. http://dx.doi.org/10.1046/j.1365-2672.2003.01853.x

[7] Fonseca, F., Passot, S., Cunin, O. and Marin, M. (2004) Collapse Temperature of Freeze-Dried Lactobacillus bulgaricus Suspensions and Protective Media. Biotechnology Progress, 20, 229-238. http://dx.doi.org/10.1021/bp034136n

[8] Rault, A., Béal, C., Ghorbal, S., Ogier, J.-C. and Bouix, M. (2007) Multiparametric Flow Cytometry Allows Rapid Assessment and Comparison of Lactic Acid Bacteria Viability after Freezing and during Frozen Storage. Cryobiology, 55, 35-43. http://dx.doi.org/10.1016/j.cryobiol.2007.04.005

[9] Meng, X.C., Stanton, C., Fitzgerald, G.F., Daly, C. and Ross, R.P. (2008) Anhydrobiotics: The Challenges of Drying Probiotic Cultures. Food Chemistry, 106, 1406-1416. http://dx.doi.org/10.1016/j.foodchem.2007.04.076

[10] Stummer, S., Toegel, S., Rabenreither, M.-C., Unger, F.M., Wirth, M., Viernstein, H. and Salar-Behzadi, S. (2012) Fluidized-Bed Drying as a Feasible Method for Dehydration of Enterococcus faecium M74. Journal of Food Engineering, 111, 156-165. http://dx.doi.org/10.1016/j.jfoodeng.2012.01.005

[11] Meng, X.C., Stanton, C., Fitzgerald, G.F., Daly, C. and Ross, R.P. (2008) Anhydrobiotics: The Challenges of Drying Probiotic Cultures. Food Chemistry, 106, 1406-1416. http://dx.doi.org/10.1016/j.foodchem.2007.04.076

[12] Stummer, S., Toegel, S., Rabenreither, M.-C., Unger, F.M., Wirth, M., Viernstein, H. and Salar-Behzadi, S. (2012) Fluidized-Bed Drying as a Feasible Method for Dehydration of Enterococcus faecium M74. Journal of Food Engineering, 111, 156-165.

[13] Carvalho, A.S., Silva, J., Ho, P., Teixeira, P., Malcata, F.X. and Gibbs, P. (2004) Relevant Factors for the Preparation of Freeze-Dried Lactic Acid Bacteria. International Dairy Journal, 14, 835-847. http://dx.doi.org/10.1016/j.idairyj.2004.02.001

[14] Strasser, S., Neureiter, M., Geppl, M., Braun, R. and Danner, H. (2009) Influence of Lyophilization, Fluidized Bed Drying, Addition of Protectants, and Storage on the Viability of Lactic Acid Bacteria. Journal of Applied Microbiology, 107, 67-177. http://dx.doi.org/10.1111/j.1365-2672.2009.04192.x

[15] Siaterlis, C. and Charalampopoulos, D.D. (2009) Effect of Culture Medium and Cryoprotectants on the Growth and Survival of Probiotic Lactobacilli during Freeze Drying. Letters in Applied Microbiology, 48, 295-301. http://dx.doi.org/10.1111/j.1472-765X.2008.02529.x

[16] Daly, C., Fitzgerald, G.F., O’Connor, L. and Davis, R. (1998) Technological and Health Benefits of Dairy Starter Cultures. International Dairy Journal, 8, 195-205. http://dx.doi.org/10.1016/S0958-6946(98)00042-9

[17] Linders, J.M., Wolkers, W.F., Hoekstra, F.A. and van't Riet, K. (1997) Effect of Added Carbohydrates on Membrane Phase Behavior and Survival of Dried Lactobacillus plantarum. Cryobiology, 35, 31-40.

http://dx.doi.org/10.1006/cryo.1997.2021 
[18] Meng, X.C., Stanton, C., Fitzgerald, G.F., Daly, C. and Ross, R.P. (2008) Anhydrobiotics: The Challenges of Drying Probiotic Cultures. Food Chemistry, 106, 1406-1416. http://dx.doi.org/10.1016/j.foodchem.2007.04.076

[19] Morgan, C.A., Herman, N., White, P.A. and Vesey, G. (2006) Preservation of Micro-Organisms by Drying: A Review. Journal of Microbiological Methods, 66, 183-193. http://dx.doi.org/10.1016/j.mimet.2006.02.017

[20] Hubalek, Z. (2003) Protectants Used in the Cryopreservation of Microorganisms. Cryobiology, 46, 205-229. http://dx.doi.org/10.1016/S0011-2240(03)00046-4

[21] Zayed, G. and Roos, Y.H. (2004) Influence of Trehalose and Moisture Content on Survival of Lactobacillus salivarius Subjected to Freeze-Drying and Storage. Process Biochemistry, 39, 1081-1086. http://dx.doi.org/10.1016/S0032-9592(03)00222-X

[22] Ming, L., Rahim, R., Wan, H. and Ariff, A. (2009) Formulation of Protective Agents for Improvement of Lactobacillus salivarius I 24 Survival Rate Subjected to Freeze Drying for Production of Live Cells in Powderized Form. Food and Bioprocess Technology, 2, 431-436. http://dx.doi.org/10.1007/s11947-009-0184-0

[23] Savini, M., Cecchini, C., Verdenelli, M.C., Silvi, S. and Orpianesi, C. (2010) Pilot-Scale Production and Viability Analysis of Freeze-Dried Probiotic Bacteria Using Different Protective Agents. Nutrients, 2, 330-339. http://dx.doi.org/10.3390/nu2030330

[24] Higl, B., Kurtmann, L., Carlsen, C.U., Ratjen, J., Forst, P., Skibsted, L.H., Kulozik, U. and Risbo, J. (2007) Impact of Water Activity, Temperature, and Physical State on the Storage Stability of Lactobacillus paracasei ssp. paracasei Freeze-Dried in a Lactose Matrix. Biotechnology Progress, 23, 794-800. http://dx.doi.org/10.1002/bp070089d

[25] Higl, B. (2008) Bedeutung der Verfahrenstechnik und das Glaszustands fuer die Stabilitaet vom Mikroorganismen waehrend der Lyophilisation und der Lagerung. Technische Universitaet Muenchen, Disseratation.

[26] Katarzyna, L., Dembczyński, R., Białas, W. and Jankowski, T. (2009) Production of Dry Lactobacillus rhamnosus Preparations by Spray Drying and Lyophilization in Aqueous Two-Phase Systems. Acta Scientiarum Polonorum: Technologia Alimentaria, 39-49.

[27] Breeuwer, P. and Abee, T. (2000) Assessment of Viability of Microorganisms Employing Fluorescence Techniques. International Journal of Food Microbiology, 55, 193-200. http://dx.doi.org/10.1016/S0168-1605(00)00163-X

[28] McDougald, D., Rice, S.A., Weichart, D. and Kjelleberg, S. (1998) Non-Culturability: Adaptation or Debilitation? FEMS Microbiology Ecology, 25, 1-9.

[29] Fonseca, F., Béal, C. and Corrieu, G. (2000) Method of Quantifying the Loss of Acidification Activity of Lactic Acid Starters during Freezing and Frozen Storage. Journal of Dairy Research, 67, 83-90. http://dx.doi.org/10.1017/S002202999900401X

[30] Rault, A., Bouix, M. and Béal, C. (2008) Dynamic Analysis of Lactobacillus delbrueckii subsp. bulgaricus CFL1 Physiological Characteristics during Fermentation. Applied Microbiology and Biotechnology, 81, 559-570.

[31] Malek, R., El-Attar, A., Mohamed, M., Anwar, S., El-Soda, M. and Béal, C. (2012) Technological and Safety Properties Display Biodiversity among Enterococci Isolated from Two Egyptian Cheeses, "Ras” and "Domiati”. International Journal of Food Microbiology, 153, 314-322. http://dx.doi.org/10.1016/j.ijfoodmicro.2011.11.019

[32] El-Soda, M., Farkye, N., Vuillemard, J., Simard, R., Olson, N., El Kholy, W., Dako, E., Medrano, E., Gaber, M. and Lim, L. (1995) Autolysis of Lactic Acid Bacteria. Impact on Flavour DEVELOPMENT in Cheese. In: Charalambous, G., Ed., Food Flavour: Generation Analysis and Process Influence, Amsterdam, 2205-2223. http://dx.doi.org/10.1016/S0167-4501(06)80283-9

[33] El Soda, M., Law, J., Tsakalidou, E. and Kalantzopoulos, G. (1995) Lipolytic Activity of Cheese-Related Microorganisms and Its Impact on Cheese Flavour. In: Charalambous, G., Ed., Food Flavors: Generation, Analysis and Process Influence, Elsevier Science, New York, 1823-1847. http://dx.doi.org/10.1016/S0167-4501(06)80267-0

[34] De Man. J.C., Rogosam, M. and Sharpe M.E. (1960) A Medium for the Cultivation of Lactobacilli. Journal of Applied Bacteriology, 23, 130-135.

[35] Terazaghi, B.K. and Sandine, W.E. (1975) Improved Medium for Lactic Streptococci and Their Bacteriophage. Journal of Applied Bacteriology, 29, 807.

[36] de Valdez, G.F., de Giori, G.S., de Ruiz Holgado, A.P. and Oliver, G. (1985) Rehydration Conditions and Viability of Freeze-Dried Lactic Acid Bacteria. Cryobiology, 22, 574-577. http://dx.doi.org/10.1016/0011-2240(85)90034-3

[37] Thiboutot, H., Dako, E., El-Soda, M., Vuillemard, J.C., Power, N. and Simard, R.E. (1995) Influence of Heat and Freeze Shocking on the Autolysis and Peptidase Activities of Lactobacillus casei. Milchwissenschaft, 50, 448-452.

[38] El-Soda, M. and Desmazeaud, M. (1982) Les peptide-hydrolase des Lactobacillus du groupe Thermobacterium. 1. Mise en évidence de ces activités chez Lactobacillus helveticus, L. lactis et L. bulgaricus. Canadian Journal of Microbiology, 28, 1181-1188. http://dx.doi.org/10.1139/m82-174

[39] Brandle, E. and Zizer, T. (1973) Über die spaltung aromatischer ester durch präparate von milkroorganismen mit liply- 
tischer und proteolytischer aktivität. Österr. Milchwirtsch. 28, 15-24.

[40] Lowry, O.H., Rosebrough, N.J., Farr, A.L. and Randall, R.J. (1951) Protein Measurement with the Folin Phenol Reagent. Journal of Biological Chemistry, 193, 265-275.

[41] Steel, R.G. and Torrie, J.H. (1980) Principles and Procedures of Statistics. 2th Edition, McGraw Hill, New York.

[42] Yao, A.A., Bera, F., Franz, C., Holzapfel, W. and Thonart, P. (2008) Survival Rate Analysis of Freeze-Dried Lactic Acid Bacteria Using the Arrhenius and Z-Value Models. Journal of Food Protection, 71, 431434.

[43] Ziadi, M., Touhami, Y., Achour, M., Thonart, P. and Hamdi, A. (2005) The Effect of Heat Stress on Freeze-Drying and Conservation of Lactococcus. Biochemical Engineering Journal, 24, 141-145. http://dx.doi.org/10.1016/j.bej.2005.02.001

[44] Andersen, A.B., Fog-Petersen, M.S., Larsen, H. and Skibsted, L.H. (1999) Storage Stability of Freeze-Dried Starter Cultures (Streptococcus thermophilus) as Related to Physical State of Freezing Matrix. LWT-Food Science and Technology, 32,540-547. http://dx.doi.org/10.1006/fstl.1999.0594

[45] King, V.A.E. and Su, J.T. (1994) Dehydration of Lactobacillus acidophilus. Process Biochemistry, 28, 47-52.

[46] Ananta, E., Volkert, M. and Knorr, D. (2005) Cellular Injuries and Storage Stability of Spray-Dried Lactobacillus rhamnosus GG. International Dairy Journal. 15, 399-409. http://dx.doi.org/10.1016/j.idairyj.2004.08.004

[47] Panoff, J.M., Thammavongs, B. and Gueguen, M. (2000) Cryoprotectants Lead to Phenotypic Adaptation to FreezeThaw Stress in Lactobacillus delbrueckii subsp. bulgaricus CIP 101027T. Cryobiology, 40, 264-269. http://dx.doi.org/10.1006/cryo.2000.2240

[48] Beal, C., Fonseca, F. and Corrieu, G. (2001) Resistance to Freezing and Frozen Storage of Streptococcus thermophilus Is Related to Membrane Fatty Acid Composition. Journal of Dairy Science, 84, 2347-2356. http://dx.doi.org/10.3168/jds.S0022-0302(01)74683-8

[49] Teixeira, P.C., Castro, M.H. and Kirby, R.M. (1996) Evidence of Membrane Lipid Oxidation of Spray-Dried Lactobacillus bulgaricus during Storage. Letters in Applied Microbiology, 22, 34-38. http://dx.doi.org/10.1111/j.1472-765X.1996.tb01103.x

[50] Beales, N. (2004) Adaptation of Microorganisms to Cold Temperatures, Weak Acid Preservatives, Low pH, and Osmotic Stress: A Review. Comprehensive Reviews in Food Science and Food Safety, 3, 1-20. http://dx.doi.org/10.1111/j.1541-4337.2004.tb00057.x

[51] Heckly, R.J. (1961) Preservation of Bacteria by Lyophilization. Advances in Applied Microbiology, 3, 1-76. http://dx.doi.org/10.1016/S0065-2164(08)70506-9

[52] Boza, Y., Barbin, D. and Scamparini, A.R.P. (2004) Effect of Spray Drying on the Quality of Encapsulated Cells of Beijerinckia sp. Process Biochemistry, 39, 1275-1284. http://dx.doi.org/10.1016/j.procbio.2003.06.002

[53] Corcoran, B.M., Ross, R.P., Fitzgerald, G.F. and Stanton, C. (2004) Comparative Survival of Probiotic Lactobacilli Spray-Dried in the Presence of Prebiotic Substances. Journal of Applied Microbiology, 96, 1024-1039. http://dx.doi.org/10.1111/j.1365-2672.2004.02219.x

[54] Desmond, C., Ross, R.P., O’Callaghan, E., Fitzgerald, G. and Stanton, C. (2002) Improved Survival of Lactobacillus paracasei NFBC 338 in Spray-Dried Powders Containing Gum Acacia. Journal of Applied Microbiology, 93, 10031011. http://dx.doi.org/10.1046/j.1365-2672.2002.01782.x

[55] Silva, J., Carvalho, A.S., Teixeira, P. and Gibbs, P.A. (2002) Bacteriocin Production by Spray-Dried Lactic Acid Bacteria. Letters in Applied Microbiology, 34, 77-81. http://dx.doi.org/10.1046/j.1472-765x.2002.01055.X

[56] Kocha, S., Eugster-Meierb, E., Obersona, G., Meilea, L. and Lacroix, C. (2008) Effects of Strains and Growth Conditions on Autolytic Activity and Survival to Freezing and Lyophilization of Lactobacillus delbrueckii ssp. lactis Isolated from Cheese. International Dairy Journal, 18, 187-196. http://dx.doi.org/10.1016/j.idairyj.2007.07.009

[57] Riveros, B., Ferrer, J. and Borquez, R. (2009) Spray Drying of a Vaginal Probiotic Strain of Lactobacillus acidophilus. Drying Technology, 27, 123-132. http://dx.doi.org/10.1080/07373930802566002

[58] El-Soda, M., El-Ziney, M., Awad, S., Osman, G., Omran, N., Gamal, G., Ezzat, N. and El Shafei, H. (2003) A Culture Collection of Lactic Acid Bacteria Isolated from Raw Milk and Traditional Egyptian Dairy Products. Egyptian Journal of Dairy Science, 31, 23-41.

[59] Husson-Kao, C., Mengaud, J., Cesselin, B., van Sinderen, D., Benbadis, L. and Chapot-Chartier, M.P. (2000) The Streptococcus thermophilus Autolytic Phenotype Results from a Leaky Prophage. Applied and Environmental Microbiology, 66, 558-565. http://dx.doi.org/10.1128/AEM.66.2.558-565.2000

[60] Franciosi, E., Settanni, L., Cavazza, A. and Poznanski, E. (2009) Biodiversity and Technological Potential of Wild Lactic Acid Bacteria from Raw Cows’ Milk. International Dairy Journal, 19, 3-11.

http://dx.doi.org/10.1016/j.idairyj.2008.07.008 
[61] Husson-Kao, C., Mengaud, J., Gripon, J.-C., Laurent, B. and Chapot-Chartier, M.-P. (1999) The Autolysis of Streptococcus thermophilus DN-001065 Is Triggered by Several Food-Grade Environmental Signals. International Dairy Journal, 9, 715-723. http://dx.doi.org/10.1016/S0958-6946(99)00145-4

[62] Frohlich-Wyder, M.T. and Bachmann, H.P. (2005) Cheeses with Propionic Acid Fermentation. In: Fox, P.F., McSweeney, P.L.H., Cogan, T.M. and Guinee, T.P., Eds., Cheese: Chemistry, Physics and Microbiology, Vol. 2, Elsevier, London, 141-156.

[63] Lortal, S. and Chapot-Chartier, M.P. (2005) Role, Mechanisms and Control of Lactic Acid Bacteria Lysis in Cheese. International Dairy Journal, 15, 857-871. http://dx.doi.org/10.1016/j.idairyj.2004.08.024 